\section{References}

1 Blair RJR, Viding E. Psychopathy. In Rutter's Child and Adolescent Psychiatry 5th Edition (eds M Rutter, D Bishop, D Pine, S Scott, J Stevenson, E Taylor, et al): 852-63. Blackwell, 2008.

2 Frick PJ, O'Brien BS, Wootton JM, McBurnett K. Psychopathy and conduct problems in children. J Abnorm Psychol 1994; 103: 700-7.

3 Viding $E$, Jones AP, Pual JF, Moffitt TE, Plomin R. Heritability of antisocial behaviour at 9: do callous-unemotional traits matter? Dev Sci 2008; 11: $17-22$.

4 Hawes DJ, Dadds MR. The treatment of conduct problems in children with callous-unemotional traits. J Consult Clin Psychol 2005; 73: 737-41.

5 Lynam DR, Caspi A, Moffitt TE, Loeber R, Stouthamer-Loeber M. Longitudinal evidence that psychopathy scores in early adolescence predict adult psychopathy. J Abnorm Psychol 2007; 116: 155-65.
6 Dadds MR, Allen JL, Oliver BR, Faulkner N, Legge K, Moul C, et al. Love, eye contact and the developmental origins of empathy $v$. psychopathy. Br J Psychiatry 2012; 200: 191-6.

7 Kumsta R, Sonuga-Barke E, Rutter M. Adolescent callous-unemotional traits and conduct disorder in adoptees exposed to severe early deprivation. Br J Psychiatry 2012; 200: 197-201.

8 Rowe R, Maughan B, Moran P, Ford T, Briskman J, Goodman R. The role of callous and unemotional traits in the diagnosis of conduct disorder. J Child Psychol Psychiatry 2010; 51: 688-95.

9 Skeem JL, Cooke DJ. Is criminal behavior a central component of psychopathy? Conceptual directions for resolving the debate. Psychol Assess 2010; 22: 433-45.

10 Jones AP, Happé FGE, Gilbert F, Burnett S, Viding E. Feeling, caring, knowing: different types of empathy deficit in boys with psychopathic tendencies and autism spectrum disorder. J Child Psychol Psychiatry 2010; 51: 1188-97.

\section{psychiatry} in pictures

\title{
Talk to Me (2010), by Susan Adams (b. 1966)
}

Susan Adams is an artist working in Brecon, South Wales. She has recently completed a project interviewing people who hear voices and producing interpretations of what they told her.

She writes: 'I am interested in the locations where the organic and the mechanical find an uneasy relationship. My recent project with people who hear voices resulted in a book They Leak Through Me, and took me further into an enquiry into the giving and receiving of information in the air. One of the voicehearers I interviewed felt almost like a receiver that was picking up other people's thoughts accidentally on the airwaves. Talk to Me is from my current series of paintings, prints and sculpture in which satellite dishes and telecommunications masts rise from the ground like hermits looking to the sky for celestial knowledge. They also transmit, and in this image with its echoes of the tree of knowledge in the Garden of Eden, we might wonder where this particular knowledge is taking us.'

A further selection of Susan Adams's prints and paintings can be found on: www.susan-adams.co.uk

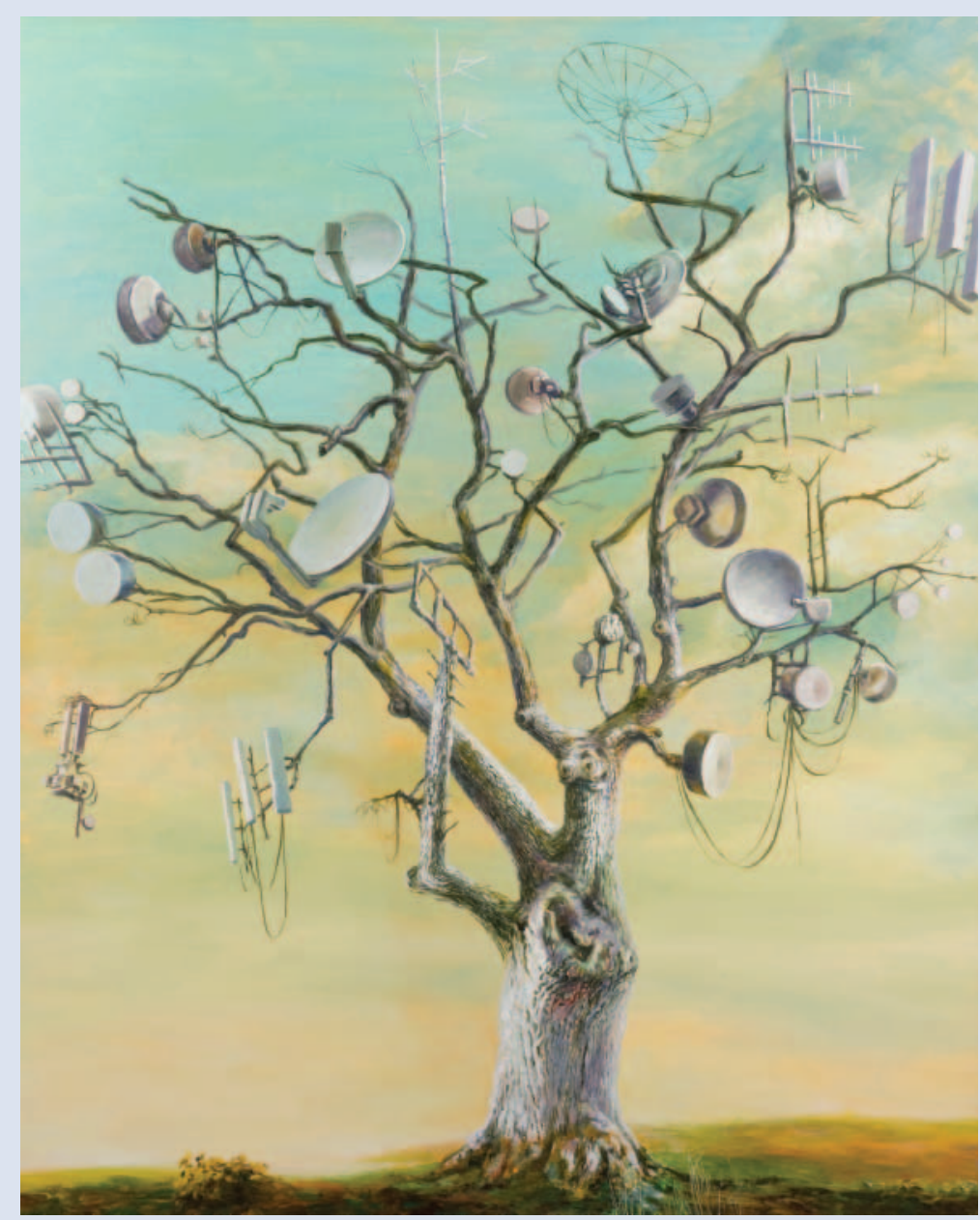

An incomplete version of this image was published on the front cover of last month's Journal. The publishers apologise for this error. 